\title{
Keefektifan Asap Cair dan Elektroterapi untuk Mengeliminasi Infeksi Xanthomonas oryzae pv. oryzae pada Benih Padi
}

\section{The Effectiveness of Liquid Smoke and Electrotherapy to Eliminate Infection of Xanthomonas oryzae pv. oryzae in Rice Seed}

\author{
Rizky Gunawan Sugeng Purnama, Kikin Hamzah Mutaqin*, Efi Toding Tondok \\ Institut Pertanian Bogor, Bogor 16680
}

\begin{abstract}
ABSTRAK
Penyakit hawar daun bakteri yang disebabkan oleh Xanthomonas oryzae pv. oryzae merupakan penyakit tular benih yang dapat menurunkan produktivitas padi. Alternatif perlakuan benih dengan perlakuan asap cair dan elektroterapi belum banyak dikembangkan. Penelitian bertujuan menentukan keefektifan perlakuan asap cair dan elektroterapi serta kombinasinya untuk membebaskan benih padi dari $X$. oryzae pv. oryzae tanpa menurunkan kualitas benih. Penelitian terdiri atas tiga tahap, yaitu: (1) Uji asap cair terhadap viabilitas bakteri dan benih padi; (2) Uji elektroterapi terhadap viabilitas bakteri dan benih padi; (3) Uji kombinasi asap cair dan elektroterapi pada benih padi terinfeksi bakteri. Hasil penelitian menunjukkan bahwa perlakuan asap cair $5 \%$ selama 30 menit mampu menurunkan populasi $X$. oryzae pv. oryzae pada benih padi sebesar $83.33 \%$ dengan vigor benih $94.33 \%$, daya berkecambah benih $98.00 \%$ dan waktu yang dibutuhkan untuk mencapai $50 \%$ total perkecambahan $\left(\mathrm{T}_{50}\right)$ ialah 3.13 hari. Perlakuan elektroterapi dengan arus listrik $400 \mathrm{~mA}$ selama 20 menit efektif mengeliminasi $X$. oryzae pv. oryzae hingga $100 \%$ dengan vigor benih sebesar $81.67 \%$, daya berkecambah $89.33 \%$, dan $\mathrm{T}_{50} 3.47$ hari. Perlakuan elektroterapi pada $400 \mathrm{~mA}$ selama 20 menit diikuti perendaman benih padi terinfeksi dalam asap cair $1 \%$ selama 30 menit mampu mengurangi populasi bakteri $94.59 \%$ dengan tetap mempertahankan daya berkecambah benih $86.00 \%$. Perlakuan elektroterapi pada $400 \mathrm{~mA}$ selama 20 menit diikuti perendaman benih ke dalam asap cair pada konsentrasi $5 \%$ selama 30 menit dapat menurunkan populasi bakteri pada benih padi hingga $100 \%$, tetapi menyebabkan fitotoksisitas pada kecambah.
\end{abstract}

Kata kunci: arus listrik, fitotoksisitas, hawar daun bakteri, jendela perlakuan, perlakuan benih

\section{ABSTRACT}

Bacterial leaf blight caused by Xanthomonas oryzae pv. oryzae is a seed-borne disease that can reduce the productivity of rice. Alternative treatments that have not been widely developed is application of liquid smoke and electrotherapy. The aim of this research was to study the effectiveness of liquid smoke and electrotherapy and their combinations to eliminate $X$. oryzae pv. oryzae without damaging seed quality. The study consisted of three experimental stages: (1) Liquid smoke treatment on the viability of the bacteria and rice seeds; (2) Electrotherapy treatment on the viability of bacteria and rice seeds; (3) Combination of liquid smoke and electrotherapy treatment in bacteria-infected rice seed. The results showed that liquid smoke concentration ( $5 \%$ for 30 minutes) was able to reduce $83.33 \%$ population of $X$. oryzae pv.oryzae on rice seeds with $94.33 \%$ seed vigor, $98.00 \%$ germination, and time required to achieve $50 \%$ of total seed emergence $\left(\mathrm{T}_{50}\right)$ of 3.13 days. Electrotherapy treatment ( $400 \mathrm{~mA}$ for 20 minutes) was not only eliminated $X$. oryzae pv. oryzae on rice seeds up to $100 \%$ but also maintained seed vigor $81.67 \%$, germination $89.33 \%$, and $\mathrm{T}_{50} 3.47$ days. Electrotherapy treatment (400 mA for 20 minutes)

*Alamat penulis korespondensi: : Departemen Proteksi Tanaman, Fakultas Pertanian, Institut Pertanian Bogor, Jalan Kamper, Kampus IPB Dramaga, Bogor 16680.

Tel: 0251-8629362, Faks: 0215-8629362, Surel: kmutaqin@gmail.com 
followed by immersion of infected rice seeds in liquid smoke concentration ( $1 \%$ for 30 minutes) could reduce $94.59 \%$ bacteria population while maintaining $86.00 \%$ seed germination. Treatment of electrotherapy ( $400 \mathrm{~mA}$ for 20 minutes) followed by immersion seeds into liquid smoke concentration ( $5 \%$ for 30 minutes) could reduce bacterial population up to $100 \%$, but caused phytotoxicity effect to the seedling.

Key words: bacterial leaf blight, electric current, phytotoxicity, seed treatment, window treatment

\section{PENDAHULUAN}

Salah satu penyakit penting padi ialah hawar daun bakteri (HDB) yang disebabkan oleh Xanthomonas oryzae pv. oryzae. Kehilangan hasil akibat HDB dapat mencapai $70-80 \%$ di Indonesia, $74-81 \%$ di India, dan 20-50\% di Jepang (Gnanamanickam et al. 1999). Bakteri ini dapat terbawa benih yang menyebabkan rendahnya kualitas benih dan terinfeksinya tanaman sejak dini.

Pengendalian yang perlu dikembangkan untuk menekan penyakit HDB ialah dengan menyediakan benih sehat sehingga diperlukan metode perlakuan benih yang sesuai agar patogen yang sudah berada di dalam benih tidak menginfeksi saat di pertanaman dan menurunkan kualitas benih. Alternatif perlakuan yang perlu dicobakan untuk bakteri patogen terbawa benih ialah penggunaan asap cair dan elektroterapi. Asap cair memiliki sifat fungsional sebagai antioksidan dan antibakteri (Yang et al. 2016). Elektroterapi adalah metode perlakuan yang telah digunakan untuk virus terbawa benih maupun tanaman, namun belum pernah dilaporkan digunakan untuk bakteri terbawa benih padi. Metode ini menggunakan listrik yang dialirkan pada jaringan tanaman untuk merusak atau mendegradasi nukleoprotein virus sehingga mengurangi bahkan menghilangkan infektivitasnya (Badarau et al. 2014).

Perlakuan untuk mengeliminasi patogen terbawa benih mensyaratkan adanya treatment window. Treatment window merupakan zona perlakuan pada saat populasi patogen sudah mulai menurun, tetapi benih tetap memiliki perkecambahan yang tinggi setelah diberikan perlakuan benih (Forsberg 2004). Penelitian ini bertujuan untuk menentukan keefektifan perlakuan asap cair, elektroterapi, dan kombinasinya untuk mengeliminasi bakteri $X$. oryzae $p v$. oryzae pada benih padi tanpa merusak kualitas benih. Perlakuan asap cair dan elektroterapi diharapkan dapat menjadi alternatif pengendalian $X$. oryzae pv. oryzae terbawa benih padi.

\section{BAHAN DAN METODE}

Asap cair yang digunakan merupakan hasil pirolisis tandan kosong kelapa sawit (TKKS) pada suhu $400{ }^{\circ} \mathrm{C}$ yang dilakukan di Laboratorium Kimia Terpadu dan Proksimat Pusat Penelitian Pengembangan Kehutanan, Gunung Batu, Bogor. Komponen kimia dari asap cair hasil pirolisis diidentifikasi dengan teknik kromatografi gas dan spektrometer massa. Komponen utama yang terkandung pada asap cair ialah asam organik, fenol, alkone, alkohol, dan ester dengan asam asetat sebagai komponen utama.

Benih padi yang digunakan ialah varietas Ciherang yang diperoleh dari lapangan di Desa Tajurhalang, Kecamatan Cijeruk, Kabupaten Bogor. Varietas Ciherang merupakan varietas unggul berpotensi hasil tinggi dan memiliki ketahanan terhadap hawar daun bakteri, khususnya galur III dan IV.

\section{Bakteri X. oryzae pv. oryzae dari Benih Padi}

Sebanyak 400 benih padi direndam dalam larutan $\mathrm{NaOCl} 1 \%$ selama 15 menit, dibilas dengan air steril, direndam dalam air hangat selama 1-2 jam, dan dibilas lagi dengan air steril. Benih ditumbuk halus dan ditambahi $50 \mathrm{~mL}$ aquades steril lalu diinkubasi pada suhu 0 sampai $4{ }^{\circ} \mathrm{C}$ selama 2 jam. Bakteri diisolasi menggunakan pengenceran berseri pada medium peptone sucrose agar 
(PSA: $10 \mathrm{~g} \mathrm{~L}^{-1}$ pepton, $10 \mathrm{~g} \mathrm{~L}^{-1}$ sukrosa, $1 \mathrm{~g} \mathrm{~L}^{-1}$ sodium glutamat, $15 \mathrm{~g} \mathrm{~L}^{-1}$ agar-agar). Koloni yang muncul diamati setelah 3 hari. Pengayaan bakteri $X$. oryzae pv. oryzae dilakukan dengan mengambil satu koloni tunggal bakteri pada medium PSA umur 72 jam dan dimasukkan ke dalam $500 \mathrm{~mL}$ medium peptone sucrose broth (PSB) dan dihomogenkan. Selanjutnya bakteri diinkubasi pada inkubator bergoyang dengan kecepatan $110 \mathrm{rpm}$ selama 24 jam. Konfirmasi isolat $X$. oryzae pv. oryzae dengan PCR dilakukan menggunakan pasangan primer spesifik XOR-F (5' GCA TGA CGT CAT CGT CCT GT-3') dan XOR-R2 (5'CTC GGA GCT ATA TGC CG TGC-3') (Adachi dan Oku 2000). Hal ini dilakukan untuk mengonfirmasi bahwa isolat patogen yang digunakan ialah $X$. oryzae pv. oryzae.

\section{Uji Asap Cair terhadap Viabilitas Bakteri dan Benih Padi}

Uji asap cair pada biakan bakteri $X$. oryzae pv.oryzae hasil isolasi dari benih padi dilakukan secara in-vitro dengan teknik peracunan medium (Mew dan Misra 1994). Larutan asap cair ditambahkan ke dalam medium PSA pada taraf konsentrasi $0.1,0.5,1,5$, dan $10 \%$. Sebanyak $100 \mu \mathrm{L}$ suspensi bakteri $\left(10^{8} \mathrm{cfu} \mathrm{mL}^{-1}\right.$, $\left.\mathrm{OD}_{600}=0.62\right)$ disebar pada medium PSA dan diinkubasi pada suhu $26{ }^{\circ} \mathrm{C}$ selama 72 jam. Koloni yang tumbuh diamati untuk menentukan kepadatan populasi bakteri.

Uji asap cair pada benih padi sehat dilakukan dengan merendam 400 benih ke dalam larutan asap cair pada taraf konsentrasi $0,0.1,0.5,1,5$, dan $10 \%(\mathrm{v} / \mathrm{v})$ dengan taraf waktu selama 30 menit, 1, 3, 6, 9, dan 12 jam. Benih padi yang telah direndam selanjutnya ditiriskan dan dikeringanginkan, kemudian disebar pada kertas merang basah sebagai substrat untuk pengamatan daya berkecambah dan indeks vigor benih.

Uji asap cair juga dilakukan terhadap benih padi varietas Ciherang terinfeksi bakteri $X$. oryzae pv. oryzae secara alami yang diperoleh dari sawah di Desa Cibalung, Kecamatan Cijeruk, Kabupaten Bogor. Metode dan taraf konsentrasi yang diberikan sama dengan uji menggunakan benih sehat, kecuali taraf waktu hanya 30 menit. Selanjutnya masing-masing $1 \mathrm{~g}$ benih digerus dalam $10 \mathrm{~mL}$ larutan $\mathrm{NaCl}$ $0.8 \%$. Sebanyak $100 \mu \mathrm{L}$ suspensi disebar pada medium PSA dan diinkubasi pada suhu $26{ }^{\circ} \mathrm{C}$ selama 72 jam. Koloni yang tumbuh diamati untuk menentukan kepadatan populasi bakteri. Benih yang tidak digerus ditumbuhkan pada tanah steril untuk diukur viabilitasnya.

\section{Uji Elektroterapi terhadap Viabilitas Bakteri dan Benih Padi}

Uji elektroterapi dilakukan dengan menempatkan suspensi $X$. oryzae pv. oryzae $\left(10^{8} \mathrm{cfu} \mathrm{mL}^{-1}\right)$ dalam larutan $\mathrm{NaCl} 1 \mathrm{M}$ dalam tangki elektroforesis yang dialiri listrik 12 volt DC pada masing-masing taraf arus 0 , $30,50,100,200,300$, dan $400 \mathrm{~mA}$ dan taraf waktu selama 5, 10, dan 20 menit. Suspensi bakteri disebar pada medium PSA dan dihitung kepadatan populasinya (Suharti et al. 2017). Demikian juga uji elektroterapi pada benih sehat dilakukan dengan memasukkan 400 benih ke dalam tangki elektroforesis dengan cara yang sama. Selanjutnya benih ditanam untuk pengamatan daya perkecambahan dan vigor seperti dalam pengujian di atas.

Pengujian elektroterapi pada benih padi terinfeksi $X$. oryzae pv. oryzae dilakukan seperti pengujian terhadap benih sehat pada taraf arus 300, 350, dan $400 \mathrm{~mA}$ selama 20 menit. Selanjutnya 100 bulir benih digerus dalam $20 \mathrm{~mL}$ larutan $\mathrm{NaCl} 0.8 \%$. Sebanyak $100 \mu \mathrm{L}$ suspensi disebar pada medium PSA, diinkubasi pada suhu $26^{\circ} \mathrm{C}$ selama 72 jam, dan dihitung kepadatan populasinya. Sebanyak 300 benih ditumbuhkan pada tanah steril untuk mengukur viabilitasnya.

\section{Uji Kombinasi Asap Cair dan Elektroterapi pada Benih Padi Terinfeksi Bakteri}

Kombinasi perlakuan asap cair dengan elektroterapi dilakukan dengan merendam benih terinfeksi $X$. oryzae pv. oryzae dalam larutan asap cair pada taraf konsentrasi $0,0.5$, 1, 3, dan 5\% (v/v) selama 30 menit sebelum atau setelah perlakuan. Selanjutnya diberi elektroterapi pada taraf arus listrik 300, 350, 
dan $400 \mathrm{~mA}$ selama 20 menit. Pengamatan viabilitas bakteri maupun viabilitas benih dilakukan seperti pada uji sebelumnya.

\section{Rancangan Percobaan dan Analisis Data}

Datahasilujiasap cair maupun elektroterapi diplotkan sebagai grafik hubungan antara masing-masing perlakuan terhadap jumlah koloni $X$. oryzae pv. oryzae dan daya berkecambah benih padi. Zona antara konsentrasi asap cair dan kuat arus listrik elektroterapi yang mampu menurunkan populasi bakteri, namun masih mempertahankan perkecambahan benih yang memadai, dijadikan dasar uji selanjutnya masing-masing perlakuan terhadap benih padi yang terinfeksi $X$. oryzae pv. oryzae.

Daya berkecambah (DB) dihitung berdasarkan persentase kecambah normal (KN) pada hitungan I (5 HST) dan II (14 HST):

$$
\mathrm{DB}=\frac{\sum \mathrm{KN} \text { hitungan } \mathrm{I}+\sum \mathrm{KN} \text { hitungan } \mathrm{II}}{\sum \text { benih yang ditanam }} \times 100 \%
$$

Indeks vigor (IV) dihitung berdasarkan persentase pada hitungan I pada uji daya berkecambah (Copeland dan McDonald 2012), yaitu 5 HST untuk benih padi:

$$
\mathrm{IV}=\frac{\sum \mathrm{KN} 5 \mathrm{HST}}{\sum \text { benih yang ditanam }} \times 100 \%
$$

$\mathrm{T}_{50}$ merupakan waktu yang dibutuhkan untuk mencapai $50 \%$ total pemunculan kecambah dengan melakukan pengamatan harian. $\mathrm{T}_{50}$ dihitung menggunakan rumus:

$$
\mathrm{T}_{50}=\mathrm{t}_{\mathrm{i}}+\frac{\mathrm{n}_{50}-\mathrm{n}_{\mathrm{i}}}{\mathrm{n}_{\mathrm{j}}-\mathrm{n}_{\mathrm{i}}} \times 100 \% \text {, dengan }
$$

$\mathrm{T}_{50}$, waktu (hari) yang dibutuhkan untuk mencapai $50 \%$ total perkecambahan; ti, waktu (hari) batas bawah sebelum mencapai $50 \%$ perkecambahan; $\mathrm{n}_{50}, \Sigma$ kecambah $50 \%$ dari total perkecambahan; ni, $\Sigma$ kecambah batas bawah sebelum mencapai 50\% total perkecambahan; nj, $\Sigma$ kecambah batas atas setelah mencapai 50\% total perkecambahan.

Data hasil pengujian asap cair dan elektroterapi disusun dalam rancangan acak lengkap (RAL) sedangkan kombinasi pengujian asap cair dan elektroterapi disusun dalam rancangan RAL faktorial. Kemudian dilakukan analisis ragam (ANOVA) serta dilanjutkan dengan uji Tukey pada $\alpha=5 \%$ menggunakan Minitab versi 17.

\section{HASIL}

\section{Karakterisasi Asap Cair}

Asap cair berwarna kuning kecokelatan sampai kehitaman dengan bau menyengat dan terdiri atas $80-90 \%$ air serta $10-20 \%$ bahan organik termasuk di dalamnya terdapat lebih dari 200 kandungan bahan kimia. Asap cair yang dihasilkan dari pirolisis tandan kosong kelapa sawit pada suhu $400{ }^{\circ} \mathrm{C}$ mengandung 8 komponen utama, yaitu asam asetat $34.88 \%$, carbamic acid phenyl ester $12.49 \%$, 2-propanone $8.43 \%$, fenol $5.06 \%$, 2 -cyclopenten $4.55 \%$, propanoic acid $3.59 \%$, cyclohexandiamine $3.55 \%$, cyclopentanetetrol $3.24 \%$, dan cyclopenten $2.55 \%$.

\section{Viabilitas Bakteri dan Benih Padi}

Rata-rata daya berkecambah benih padi setelah perendaman pada asap cair selama 30 menit berkisar antara 91\% dan 98\% (Tabel 1). Perlakuan asap cair terhadap $X$. oryzae pv. oryzae dengan metode peracunan medium menunjukkan bahwa populasi bakteri berkurang seiring dengan meningkatnya konsentrasi asap cair yang digunakan. Asap cair menghambat pertumbuhan $X$. oryzae pv. oryzae pada konsentrasi $0.1 \%$, namun dengan penghambatan pertumbuhan yang tidak nyata. Asap cair dengan konsentrasi 1, 5, dan 10\% dapat mengeliminasi bakteri $X$. oryzae pv. oryzae hingga $100 \%$ pada kondisi in vitro (Gambar 1). Berdasarkan uji ini, konsentrasi asap cair dan kisaran waktu perendaman benih padi yang layak digunakan pada uji lanjut ialah konsentrasi $0.5 \%$ hingga 5\% selama 30 menit.

Berdasarkan treatment window, konsentrasi asap cair yang dipilih untuk perlakuan pada benih yang terinfeksi bakteri $X$. oryzae pv. oryzae ialah $0.5,1,3$, dan $5 \%$ $(\mathrm{v} / \mathrm{v})$. Perlakuan asap cair dengan konsentrasi $0.5,1,3$, dan 5\% selama 30 menit tidak menimbulkan efek buruk terhadap viabilitas benih padi. Vigor benih mencapai 89.67$95.00 \%$, daya kecambah benih 91-98\%, 
Tabel 1 Pengaruh perlakuan asap cair hasil pirolisis tandan kosong kelapa sawit terhadap viabilitas benih padi dan populasi Xanthomonas oryzae pv. oryzae terbawa benih

\begin{tabular}{lcccc}
\hline $\begin{array}{c}\text { Konsentrasi asap cair } \\
(\%)\end{array}$ & $\begin{array}{c}\text { Vigor benih } \\
(\%)\end{array}$ & $\begin{array}{c}\text { Daya berkecambah benih } \\
(\%)\end{array}$ & $\begin{array}{c}\mathrm{T}_{50} \\
(\text { hari })\end{array}$ & $\begin{array}{c}\text { Populasi bakteri } \\
\text { (cfu g-1 benih) }\end{array}$ \\
\hline Kontrol & $94.00 \mathrm{a}$ & $97.00 \mathrm{a}$ & $2.93 \mathrm{a}$ & $3.8 \times 10^{8} \mathrm{a}$ \\
0.5 & $93.67 \mathrm{a}$ & $94.33 \mathrm{a}$ & $2.85 \mathrm{a}$ & $2.2 \times 10^{8} \mathrm{ab}$ \\
1.0 & $95.00 \mathrm{a}$ & $95.67 \mathrm{a}$ & $2.72 \mathrm{a}$ & $2.0 \times 10^{8} \mathrm{ab}$ \\
3.0 & $89.67 \mathrm{a}$ & $91.00 \mathrm{a}$ & $2.86 \mathrm{a}$ & $0.9 \times 10^{8} \mathrm{~b}$ \\
5.0 & $94.33 \mathrm{a}$ & $98.00 \mathrm{a}$ & $3.13 \mathrm{a}$ & $0.6 \times 10^{8} \mathrm{~b}$ \\
\hline
\end{tabular}

$\mathrm{T}_{50}$, Waktu (hari) yang dibutuhkan untuk mencapai $50 \%$ total perkecambahan

Angka yang diikuti huruf yang sama pada lajur yang sama menunjukkan tidak berbeda nyata (uji Tukey, $\alpha=5 \%$ )

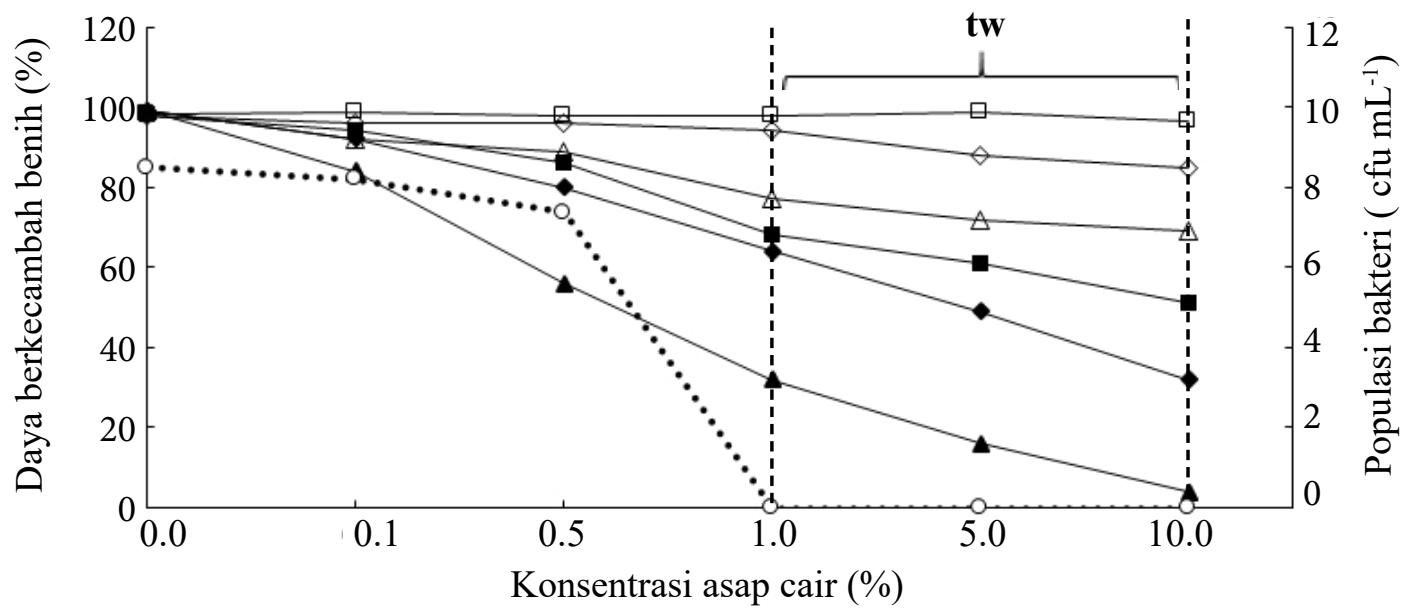

Gambar 1 Pengaruh perlakuan asap cair terhadap populasi $X$. oryzae pv oryzae (०) dan daya berkecambah benih padi (pada perendaman $\square, 30$ menit; $\diamond, 1$ jam; $\Delta, 3$ jam; $\mathbf{m}, 6$ jam; $\checkmark, 9$ jam;dan $\boldsymbol{\Lambda}, 12$ jam). tw, daerah treatment window/ konsentrasi asap cair yang sesuai untuk perlakuan benih.

$\mathrm{T}_{50}$ sebesar2.72-3.13 hari, dan semuaperlakuan tidak berbeda dengan kontrol. Konsentrasi asap cair $0.5 \%$ dan $1 \%$ tidak berbeda nyata dengan kontrol dalam menghambat pertumbuhan bakteri. Pada konsentrasi 3\% dan 5\%, asap cair dapat menghambat pertumbuhan bakteri (Tabel 1).

Elektroterapi pada benih padi tidak berpengaruh terhadap viabilitas benih (Gambar 2). Perlakuan elektroterapi dengan kuat arus listrik 30, 50,100,200,300, dan $400 \mathrm{~mA}$ selama 20 menit memiliki nilai persentase viabilitas benih pada kisaran $98 \%$, tidak berbeda bila dibandingkan dengan tanpa perlakuan (kontrol). Perlakuan elektroterapi dengan kuat arus $400 \mathrm{~mA}$ selama 20 menit efektif mengeliminasi populasi bakteri $X$. oryzae pv. oryzae hingga $100 \%$ dengan daya berkecambah benih yang masih tinggi, yaitu sebesar $98.58 \%$.

Berdasarkan treatment window, kuat arus listrik elektroterapi yang digunakan untuk perlakuan benih terinfeksi X. oryzae pv. oryzae ialah 300, 350, dan $400 \mathrm{~mA}$. Pada interval suhu tersebut daya berkecambah, indeks vigor, dan $\mathrm{T}_{50}$ benih padi masih tinggi dan populasi $X$. oryzae pv. oryzae sudah mengalami penurunan. Pengaruh perlakuan elektroterapi terhadap benih padi terinfeksi $X$. oryzae pv. oryzae menunjukkan perlakuan kuat arus listrik tidak menurunkan daya berkecambah benih padi karena daya berkecambahnya di atas $80 \%$. Perlakuan elektroterapi pada kuat arus $350 \mathrm{~mA}$ mampu mengurangi populasi bakteri yang tumbuh, dan kuat arus $400 \mathrm{~mA}$ dapat mengeliminasi bakteri hingga 100\% (Tabel 2). 


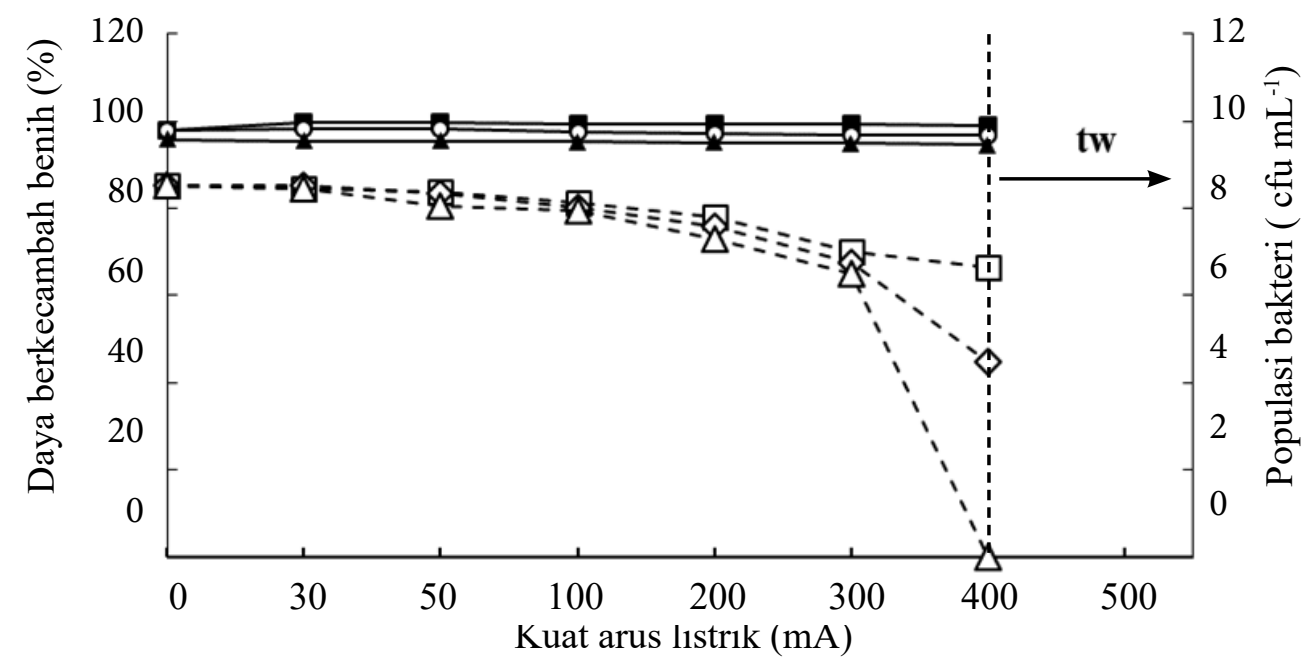

Gambar 2 Pengaruh perlakuan elektroterapi terhadap daya berkecambah benih padi (घ, 5 menit; $\circ, 10$ menit; $\boldsymbol{\Lambda}, 20$ menit) dan populasi bakteri $X$. oryzae pv. oryzae setelah paparan elektroterapi ( $\square, 5$ menit; $\diamond, 10$ menit; $\Delta, 20$ menit). tw, daerah treatment window/ kuat arus listrik yang sesuai untuk perlakuan benih.

Tabel 2 Pengaruh perlakuan elektroterapi terhadap viabilitas benih padi dan populasi Xanthomonas oryzae pv. oryzae terbawa benih

\begin{tabular}{lcccc}
\hline $\begin{array}{l}\text { Arus listrik } \\
(\mathrm{mA})\end{array}$ & $\begin{array}{c}\text { Vigor benih } \\
(\%)\end{array}$ & $\begin{array}{c}\text { Daya berkecambah benih } \\
(\%)\end{array}$ & $\begin{array}{c}\mathrm{T}_{50} \\
(\text { hari })\end{array}$ & $\begin{array}{c}\text { Populasi bakteri } \\
(\text { cfu g }\end{array}$
\end{tabular}

Angka yang diikuti huruf yang sama pada lajur yang sama menunjukkan tidak berbeda nyata (uji Tukey, $\alpha=5 \%$ )

\section{Kombinasi Perlakuan Asap Cair dan Elektroterapi pada Benih Padi Terinfeksi \\ X. oryzae pv. oryzae}

Perlakuan elektroterapi pada kuat arus $400 \mathrm{~mA}$ selama 20 menit yang dilanjutkan perendaman dengan asap cair konsentrasi 3\% dan 5\% selama 30 menit efektif menekan $X$. oryzae pv. oryzae pada benih padi karena mampu menurunkan populasi $X$. oryzae $\mathrm{pv}$. oryzae masing-masing $98.33 \%$ dan $100 \%$ (Tabel 3). Hasil terbaik kombinasi perlakuan untuk menekan populasi bakteri pada benih padi ialah perlakuan elektroterapi dengan kuat arus listrik $400 \mathrm{mAselama} 20$ menit dilanjutkan dengan perendaman asap cair dengan konsentrasi 1\% selama 30 menit. Perlakuan ini dapat menurunkan populasi bakteri mencapai $94.59 \%$ dan daya berkecambah benih $86 \%$.

\section{PEMBAHASAN}

Hasil penelitian menunjukkan bahwa perlakuan asap cair $0.5,1,3$, dan 5 selama 30 menit tidak menimbulkan efek buruk terhadap viabilitas benih padi. Daya berkecambah benih pada semua tingkat konsentrasi asap cair rata-rata mencapai 9198\%. Hasil ini lebih tinggi dari persyaratan Kementan (2015), yaitu $80 \%$. Jianming (2003) melaporkan perlakuan asap cair pada benih, pembibitan, maupun pertumbuhan lainnya tidak berpengaruh pada pertumbuhan tanaman, tetapi berpengaruh pada hasil panen dengan meningkatnya produksi padi.

Kelompok senyawa penyusun terbesar dalam asap cair yang bekerja saling sinergis dan berfungsi sebagai antibakteri ialah senyawa 
Tabel 3 Pengaruh perlakuan kombinasi asap cair dari tandan kosong kelapa sawit (TKKS) dan elektroterapi terhadap daya berkecambah benih padi dan populasi Xanthomonas oryzae pv. oryzae terbawa benih

\begin{tabular}{|c|c|c|c|c|c|}
\hline \multicolumn{6}{|c|}{ Pengamatan pada kombinasi perlakuan } \\
\hline \multirow{2}{*}{$\begin{array}{l}\text { Arus } \\
(\mathrm{mA})\end{array}$} & \multicolumn{5}{|c|}{ Konsentrasi asap cair (\%) } \\
\hline & Kontrol & 0.5 & 1.0 & 3.0 & 5.0 \\
\hline \multicolumn{6}{|c|}{ Percobaan seri I (Asap cair + Elektroterapi) } \\
\hline \multicolumn{6}{|c|}{ Daya Berkecambah (\%) } \\
\hline 300 & $89.33 \mathrm{abc}$ & $84.00 \mathrm{cdef}$ & $81.33 \mathrm{fg}$ & $74.67 \mathrm{~h}$ & $72.67 \mathrm{~h}$ \\
\hline 350 & $90.00 \mathrm{ab}$ & $91.00 \mathrm{a}$ & 87.33 abcde & 82.00 efg & $74.67 \mathrm{~h}$ \\
\hline 400 & $89.67 \mathrm{ab}$ & 85.33 bcdef & $82.00 \mathrm{efg}$ & $76.67 \mathrm{gh}$ & $73.33 \mathrm{~h}$ \\
\hline \multicolumn{6}{|c|}{ Populasi bakteri (cfu/g) } \\
\hline 300 & $3.60 \times 10^{8} \mathrm{a}$ & $2.68 \times 10^{8} \mathrm{bc}$ & $2.16 \times 10^{8} \mathrm{~cd}$ & $1.68 \times 10^{8} \mathrm{de}$ & $1.66 \times 10^{8} \mathrm{de}$ \\
\hline 350 & $3.12 \times 10^{8} \mathrm{ab}$ & $0.79 \times 10^{8} \mathrm{fg}$ & $0.55 \times 10^{8} \mathrm{ghi}$ & $0.40 \times 10^{8}$ ghij & $0.27 \times 10^{8}$ ghij \\
\hline 400 & $3.58 \times 10^{8} \mathrm{a}$ & $0.24 \times 10^{8}$ hij & $0.43 \times 10^{8}$ ghij & $0.24 \times 10^{8} \mathrm{hij}$ & $0.12 \times 10^{8} \mathrm{ij}$ \\
\hline \multicolumn{6}{|c|}{ Penurunan populasi bakteri (\%) } \\
\hline 300 & $0.00 \mathrm{i}$ & $22.38 \mathrm{~h}$ & $36.76 \mathrm{~g}$ & $51.30 \mathrm{f}$ & $51.30 \mathrm{f}$ \\
\hline 350 & $0.00 \mathrm{i}$ & $76.58 \mathrm{~cd}$ & $84.06 \mathrm{bc}$ & $87.95 \mathrm{abc}$ & $92.16 \mathrm{ab}$ \\
\hline 400 & $0.00 \mathrm{i}$ & $92.81 \mathrm{ab}$ & $88.26 \mathrm{abc}$ & $92.96 \mathrm{ab}$ & $96.53 \mathrm{ab}$ \\
\hline \multicolumn{6}{|c|}{ Percobaan seri II (Elektroterapi + Asap cair) } \\
\hline \multicolumn{6}{|c|}{ Daya Berkecambah (\%) } \\
\hline 300 & $89.00 \mathrm{abc}$ & $89.00 \mathrm{abc}$ & $89.00 \mathrm{abc}$ & 86.00 bcdef & $81.00 \mathrm{fg}$ \\
\hline 350 & $89.67 \mathrm{ab}$ & $88.67 \mathrm{abc}$ & $88.00 \mathrm{abc}$ & 82.33 def & $81.00 \mathrm{fg}$ \\
\hline 400 & $90.00 \mathrm{ab}$ & $87.67 \mathrm{abcd}$ & 86.00 abcdef & $82.33 \mathrm{def}$ & $81.00 \mathrm{fg}$ \\
\hline \multicolumn{6}{|c|}{ Populasi bakteri (cfu/g) } \\
\hline 300 & $3.60 \times 10^{8} \mathrm{a}$ & $1.41 \times 10^{8} \mathrm{e}$ & $1.19 \times 10^{8}$ ef & $0.78 \times 10^{8} \mathrm{fgh}$ & $0.56 \times 10^{8} \mathrm{ghi}$ \\
\hline 350 & $3.12 \times 10^{8} \mathrm{ab}$ & $0.76 \times 10^{8} \mathrm{fgh}$ & $0.54 \times 10^{8} \mathrm{ghi}$ & $0.37 \times 10^{8}$ ghij & $0.26 \times 10^{8}$ ghij \\
\hline 400 & $3.58 \times 10^{8} \mathrm{a}$ & $0.34 \times 10^{8}$ ghij & $0.18 \times 10^{8} \mathrm{ij}$ & $0.06 \times 10^{8} \mathrm{ij}$ & $0.00 \times 10^{0} \mathrm{j}$ \\
\hline \multicolumn{6}{|c|}{ Penurunan populasi bakteri (\%) } \\
\hline 300 & $0.00 \mathrm{i}$ & 58.92 ef & $65.40 \mathrm{de}$ & $77.44 \mathrm{~cd}$ & $83.72 \mathrm{bc}$ \\
\hline 350 & $0.00 \mathrm{i}$ & $77.52 \mathrm{~cd}$ & $84.34 \mathrm{bc}$ & $89.10 \mathrm{abc}$ & $92.35 \mathrm{ab}$ \\
\hline 400 & $0.00 \mathrm{i}$ & $90.00 \mathrm{abc}$ & $94.59 \mathrm{ab}$ & $98.33 \mathrm{a}$ & $100.00 \mathrm{a}$ \\
\hline
\end{tabular}

Angka yang diikuti huruf yang sama pada kolom dan baris yang sama menunjukkan hasil yang tidak berbeda nyata berdasarkan uji Tukey pada $\alpha=5 \%$.

fenol dan senyawa asam (Mu et al. 2003). Fenol diduga berperan sebagai antioksidan dan antibakteri. Senyawa fenol merupakan senyawa penting yang memengaruhi kualitas dari asap cair karena mampu merusak membran sel, menonaktifkan enzim dan mendenaturasi protein sehingga dinding sel mengalami penurunan permeabilitas. Perubahan permeabilitas membran sitoplasma memungkinkan terganggunya transportasi ion-ion organik yang penting ke dalam sel sehingga berakibat terhambatnya pertumbuhan bahkan hingga kematian sel (Damayanti dan Suparjana 2007). Kandungan asam dalam asap cair merupakan molekul asam lemah yang terdisosiasi (menghasilkan ion $\mathrm{H}^{+}$dan anion) menyebabkan penurunan $\mathrm{pH}$ lingkungan dan dapat kontak dengan dinding sel bakteri, membran sel, permukaan luar sitoplasma sehingga menyebabkan efek kerusakan pada sel bakteri. Pada $\mathrm{pH}$ lingkungan yang sangat rendah, asam asetat dapat menyebabkan denaturasi enzim dan ketidakstabilan permeabilitas membran sel bakteri sehingga menghambat pertumbuhan dan menurunkan daya hidup bakteri atau mikrob lainnya (Akbar et al. 2013).

Perlakuan elektroterapi efektif mengeliminasi populasi $X$. oryzae pv. oryzae dengan daya berkecambah benih yang masih tinggi. Proses yang terjadi pada perlakuan elektroterapi melibatkan larutan $\mathrm{NaCl}$ sebagai 
larutan elektrolit setelah dipapar dengan aliran listrik menyebabkan terjadinya reaksi elektrokimia. Reaksi elektrokimia melibatkan perpindahan elektron-elektron bebas menuju komponen di dalam larutan. Elektrolisis pada elektroda menghasilkan berbagai oksidan seperti oksigen, hidrogen peroksida dan ozon, serta klorin bebas dan klor dioksida apabila ion klorida terdapat dalam larutan. Oksidan tersebut bertanggung jawab atas sebagian besar kematian bakteri setelah dipapar aliran listrik arus searah (Liu et al. 1997). Hal tersebut sejalan dengan pendapat Davis et al. (1993) yang menyatakan bahwa arus listrik akan mampu membunuh populasi mikrob pada saat arus listrik dilewatkan pada larutan elektrolit yang mengandung ion klorida. Penurunan jumlah koloni bakteri terjadi karena perlakuan elektroterapi dapat mengubah susunan protein yang berada di dalam membran sel patogen. Inaktivasi nukleoprotein spesifik yang bertanggung jawab atas pergerakan sel ke sel dapat membantu mencegah penyebaran patogen ke jaringan sehat (Houllou et al. 2015).

Davis et al. (1993) membuktikan bahwa perlakuan listrik dapat menghambat atau menghentikan pertumbuhan bakteri dengan menghasilkan garam logam atau garam yang mengandung klorida. Larutan yang mengandung ion klorida menghasilkan biosida berbasis klorin yang menyebabkan efek antimikrob. Aliran listrik searah menyebabkan kompleks pori pada dinding sel bakteri membuka untuk melakukan difusi molekul hidrofilik sehingga ion klorida dapat melewati dinding sel dan berinteraksi dengan membran sel bagian dalam yang menyebabkan bakteri menjadi sangat rentan.

Faktor waktu aplikasi asap cair (sebelum dan setelah perlakuan elektroterapi) berpengaruh terhadap penurunan populasi bakteri yang terdapat di dalam benih, vigor dan daya berkecambah benih. Perlakuan elektroterapi dengan kuat arus $400 \mathrm{~mA}$ selama 20 menit yang dilanjutkan perendaman dengan asap cair konsentrasi 3 dan 5\% selama 30 menit mampu menurunkan populasi bakteri secara nyata, namun perlakuan tersebut lebih fitotoksik pada kecambah dibandingkan dengan perlakuan lainnya. Efek fitotoksik tersebut dapat dilihat dari terjadinya klorosis berupa pucat pada bagian tulang daun bahkan seluruh bagian tanaman. Menurut Neergaard (1977) fitotoksik pada kecambah dapat terjadi akibat kombinasi perlakuan benih menggunakan bahan kimia yang tidak sesuai karena memiliki efek yang berbeda satu dengan lainnya.

Asap cair dan elektroterapi yang diaplikasikan secara tunggal maupun kombinasi mampu membebaskan benih padi dari $X$. oryzae pv. oryzae tanpa menurunkan kualitas benih secara nyata sehingga dapat dijadikan sebagai alternatif pengendalian untuk mengeliminasi $X$. oryzae pv. oryzae pada benih padi.

\section{UCAPAN TERIMA KASIH}

Penulis mengucapkan terima kasih kepada Badan Karantina Pertanian yang telah memberi beasiswa pascasarjana kepada penulis.

\section{DAFTAR PUSTAKA}

Adachi N, Oku T. 2000. PCR-mediated detection of Xanthomonas oryzae pv. oryzae by amplification of the $16 \mathrm{~S}-23 \mathrm{~S}$ rDNA spacer region sequence. J Gen Plant Pathol. 6(4):303-309. DOI: https://doi. org/10.1007/PL00012969.

Akbar A, Paindoman R, Coniwanti P. 2013. Pengaruh variabel waktu dan temperatur terhadap pembuatan asap cair dari limbah kayu pelawan (Cyanometra cauliflora). J Tek Kim. 19(1):1-8.

Badarau CL, Florentina D, Chiru N. 2014. Effects of some electrotherapy treatments of pvx infected potato plantlets cv. Roclas, on several biological development indicators. J Hortic For Biotchnol. 18(3):25-29.

Copeland LO, McDonald M. 2012. Principles of seed science and technology: Springer Science \& Business Media.

Damayanti E, Suparjana T. 2007. Efek penghambatan beberapa fraksi ekstrak buah mengkudu terhadap Shigella dysentriae. Di dalam: Prosiding Seminar 
Nasional Teknik Kimia "Kejuangan", 2007 Jan 30; Sleman-Yogyakarta (ID): Universitas Jenderal Soedirman.

Davis C, Wagel N, Anderson M, Warren M. 1993. Iontophoresis and chloridecontaining compounds: parameters required for killing. J Urol. 150(4):11721175. DOI: http://dx.doi.org/10.1016/ S0022-5347(17)35717-8.

Forsberg G. 2004. Control of cereal seed-borne diseases by hot humid air seed treatment [tesis]. Uppsala (SE): Swedish University of Agricultural Sciences.

Gnanamanickam S, Priyadarisini VB, Narayanan N, Vasudevan P, Kavitha S. 1999. An overview of bacterial blight disease of rice and strategies for its management. Current Sci. 77(11):14351444.

Houllou LM, Torres DC, Medeiros MJ, Dantas PV, Soares AB, RA. dS, P dFC, MC dMS. 2015. Electrotherapy treatment for ratoon stunting disease (Leifsonia xyli subsp. xyli) elimination insugarcane. Int $\mathrm{J}$ Curr Res. 7(9):19888-19892.

Jianming Z. 2003. Effect of the solution of wood vinegar on yield and nitrogenutilization of rice. J Anhui Agric Sci. 31(4):542-543.
[Kementan] Kementerian Pertanian RI. 2015. Kepmentan RINo. 355/HK.130/C/05/2015 tentang Pedoman Sertifikasi Benih Bina Tanaman Pangan. Jakarta (ID): Kementan. Liu W-K, Brown M, Elliott T. 1997. Mechanisms of the bactericidal activity of low amperage electric current (DC). J Antimicrob Chemother. 39(6):687-695. DOI: https://doi.org/10.1093/jac/39.6.687

Mew TW, Misra J. 1994. A manual of rice seed health testing. Los Banos (PH): IRRI.

Neergaard P. 1977. Seed pathology. Basingstoke-London (UK): The MacMillan Press LTD. DOI: https://doi. org/10.1007/978-1-349-02842-9.

Suharti T, Joko T, Arwiyanto T. 2017. Deteksi bakteri patogen terbawa benih akor (Acacia auriculiformis A. Cunn. ex Benth.). JHPT Trop. 17(1):19-36. DOI: https://doi. org/10.23960/j.hptt.11719-36.

Yang J-F, Yang C-H, Liang M-T, Gao Z-J, Wu Y-W, Chuang L-Y. 2016. Chemical composition, antioxidant, and antibacterial activity of wood vinegar from Litchi chinensis. Molecules. 21(9):1150. DOI: https://doi.org/10.3390/ molecules 21091150 . 